\title{
A Systematic Review of Queue Management System: A Case of Prolonged Wait Times in Hospital Emergency Rooms
}

\author{
Ajibike. O. Itegboje ${ }^{1}$ (Ph.D), Yekini N. Asafe ${ }^{2}$ \\ 1Department of Computer Technology, Yaba College of Technology, Lagos-Nigeria \\ 2Department of Computer Engineering, Yaba College of Technology, Lagos-Nigeria \\ ${ }^{*}$ Corresponding Author \\ Ajibike. O. Itegb \\ Article History \\ Received: 06.07.2019 \\ Accepted: 12.07.2019 \\ Published: 30.07 .2019
}

\begin{abstract}
Prolonged wait times in hospital emergency rooms is a growing concern for many, because of its many effects such as, overcrowding, patients leaving out of frustration without receiving medical attention, patients' and their relatives' irrational behaviors, as well as stress on both staff and patients. The main goal of this paper is to research the various methods used to reduce prolonged wait time; methods which range from staff increase, to reviewing of processes, and to opening of alternative care centers. Though there are many methods, but one method that has reduced time spent in hospitals by patients is the application of medical informatics. Hence, it is anticipated that medical informatics will similarly reduce wait times in ERs. Therefore, this review will analyze the various methods currently being used for reducing wait times and align it with medical informatics solutions. Discussions are along the lines of: focus of previous research, the methodologies used for these research, findings and gaps in the research. According to literature search, the dominant areas in medical informatics research are electronic medical records (EMRs) and personal health records (PHRs). Another less dominant area of research is management of wait time using medical informatics. This review may assist in identifying future directions for research on prolonged wait time reduction and medical informatics.
\end{abstract}

Keywords: queues management, Prolonged wait-time, emergency departments (EDs), emergency rooms (ERs), accident \& emergency departments (A\&E), medical informatics, in-patients, out-patients

\section{INTRODUCTION}

A queue management system is an approach to control queues of people in various situations and locations in a queue area. The process of queue formation and propagation is defined as queuing theory. Some typical areas of application of queuing theory can be found in medical doctor's office, access to diagnostic procedures, specialist referrals, airports check-in, baggage collection, runway delays, waiting to land, Traffic congestion etc. Buzacott [1]. Prolonged wait time in hospitals, clinics and emergency rooms (ERs) could become unwieldy for a sick patient, and may lead to irrational behaviors such as patients leaving the hospital without receiving treatment-causing treatable diseases to become untreatable, which could lead to avoidable adverse consequences. Studies have shown that prolonged wait times in emergency rooms have led to frustration for patients who visit ERs, and cause stress to both patients and staff in ERs. Currently, the U. S. government's concern is provision of quality health care and wellness for its citizen, which the effect of prolonged wait time does not align with. This is the rationale for this review on management of prolonged wait times in ERs.

\section{Objectives of the Review}

The objectives of this review are to appraise:

- Research studies on prolonged wait-times in ERs.

- Methods that have been used and are currently being used to reduce the wait times in ERs.

- Propose an informatics solution to reduce prolonged wait times.

Hence, this review is guided by four research questions:

1. What are the causes of prolonged wait times in ERs?

Copyright @ 2019: This is an open-access article distributed under the terms of the Creative Commons Attribution license which permits unrestricted use, distribution, and reproduction in any medium for non commercial use (NonCommercial, or CC-BY-NC) provided the original author and source are credited. 
2. What are the effects of prolonged wait times in ERs on patients?

3. What are the methods for reducing wait times in ERs?

4. How can medical informatics improve existing methods for reducing wait times in ERs?

\section{BACKGROUND TO THE STUDY}

Okoli and Schabram [2] recommend that, for a literature review to be scientifically rigorous, certain steps are essential guidelines to document the search. In line with their recommendations, this review is described with reference to the search process, the practical screening which involves inclusion and exclusion criteria, data extraction, summary of the search and the write up. This review is outlined under seven sections:

- $\quad$ ERs and the services rendered in ERs

- Types of wait times in ERs and the causes of each type

- Effects of prolonged wait times in ERs

- Patients perception of quality healthcare and the importance of reduced wait times

- Medical Informatics

- Measures for reducing wait times

- $\quad$ The implication for medical practice and medical informatics

\section{METHODOLOGY}

Patients' reactions to wait time at doctor's office and the solutions for ameliorating the wait time span across a range of fields, such as medical, business practice, psychology and technology. The search strategy for this review used the media listed below: EBSCO Host at Louisiana State University and Southern University library-- Academic Search Complete, Alt HealthWatch, MedicLatina, Health Source: Nursing/Academic Edition, Hospital \& Tourism Index, Psychology and Behavioural Sciences collection, MEDLINE, PsycINFO, Information Science and Technology Abstract, as well as Google Scholar

\section{Search Terms}

The following keywords were used for the search in those media - "Wait time in Physicians' office", "Outpatient clinic wait time", "Causes of wait times in ERs", "Effects of prolonged wait times in ERs, "Solutions to prolonged wait times in ERs", and "Impact of medical informatics on wait times in hospitals."

\section{Exclusion/Inclusion Criteria} to be cited.

The research questions guided the inclusion of articles to review. The following criteria were used for the inclusion of articles

1. Peer reviewed and full text

2. The use of computers in medicine dates back to the 20th century, but medical informatics became prominent in the early $21^{\text {st }}$ century.

The search was therefore limited to research studies from 1960-2012. This will enable the reviewer analyze the trend of methods used earlier and those currently been used to reduce wait times in ERs. Forty-five articles were reviewed but eighteen met the inclusion criteria, a summary of thirteen of the articles are shown in table 1.

\section{DISCUSSION OF FINDINGS}

The discussion of findings in this review is as tabulated in table 1, but for purposes of summary this discussion is set out below.

\section{Emergency Rooms}

Emergency departments (EDs), emergency rooms (ERs), accident and emergency departments (A\&E) are terms used for the departments set up in hospitals for the treatment of critical medical conditions requiring prompt attention-such conditions as, injury due to accidents and critical illnesses. ERs are open for medical care 24 hours a day, 7 days a week. Although ERs are primarily set up for emergency cases but a number of factors, such as government policies -- the 1986 Emergency Medical Treatment and Labor Act, directed that all patients reporting to the ERs in the United States be medically screened whether they are able to pay or not [3]. Inability to afford medical insurance and primary physicians by some patients, have led to these patients patronizing ERs, thus causing ERs to extend their services to non-critical cases $[4,5,6]$.

Patients come to the ERs at different times but it is reported that during weekends and festive periods there are more patients recorded. On arrival, registration takes place and thereafter the patient's condition is reviewed by a nurse and a record is generated. The critically ill or seriously injured are promptly attended to irrespective of their arrival time, while the less critically ill are attended to on a rotational basis. The AMERICAN COLLEGE OF EMERGENCY PHYSICIANS [7] explained that this rotational attendance is based on availability of treatment rooms. 


\section{Wait Times in ERs}

Services are rendered to clients on a rotational basis of who comes in first, to avoid preferential treatment which may lead to chaos. So the time between when a person arrives for a service and when he or she is attended to is referred to as the wait time. In hospitals or ERs, the wait time is the time from when a patient comes in, through registration to seeing the physician, to the collection of medications at the pharmacy and to being discharged to return home. This time may however be extended further if the patient is evaluated to need admission into the in-patient ward.

Research on causes of prolonged wait times in ERs has not been conclusive and there is also a shortage of such research as reported in literature searched. Chan, Arendts, and Wong [8] reported that data was collected to investigate causes of prolonged wait time using a diagnostic software and staff perception. In this study, the causes of wait times identified by staff did not correlate with causes identified by the diagnostic software. The causes of delay at ERs is a complex process involving other departments of the hospital e.g., waiting for diagnostic results, review by specialist doctors, waiting for bed spaces in the in-patient ward, as well as other unpredictable factors at the ERs. An informatics system as evidenced by the study of [8] is a better determinant for causes of wait time, because it is believed to have the potential for accuracy, objectivity and impartial assessment of causal factors, except that its efficiency is dependent on human interaction.

\section{Effects of Long Wait Times in ERs}

Prolonged wait time may become unwieldy for a sick patient and the possibility of aggravating the patient's behavior cannot be ruled out. Thus, articles reviewed reported cases of unacceptable consequences as a result of untimely care. The main causes of overcrowding and irrational behaviors from patients were found to be patient's perception of his or her case as being more urgent than the other person and lack of a full understanding of the triage categories.

\section{Patients' Perception of Quality Healthcare}

A person's perception is an interpretation of what goes on in his or her environment. What is perceived as a long wait time may not be long to another person depending on the expectation of the patient's visit to the ER. Growth and Gilliland [9] findings in their studies of wait time reported that wait time had little impact on patients' perception of quality health care and this they reported was consistent with similar studies. But Blake, \& Carter, [10] Hoskins, Sayger, \& Westman, [11] Eilers, [12] King, Ben-Tovim, \& Bassham, [13] reported that patients' perception of the quality of care they received is measured by the wait time, and the willingness of the facility to provide information. In spite of these contradictions it is expected that a reduction in wait time will no doubt reduce or eliminate some of the unacceptable consequences in ERs.

\section{Medical Informatics}

Medical informatics has been defined as a discipline at the intersection of information science, computer science, and health care. It encompasses all areas of the resources, devices, and methods required to improve the acquisition, storage, retrieval, and use of information in health care and biomedicine. Examples of medical informatics are electronic health records (EHR), personal health records (PHR), population health management (PHM) and telemedicine. Protti [14] predicted that the health care system is going to be dependent on evidence based management and evidence-based medicine driven by evidence-based computing. His prediction no doubt has come to past; as the U.S. government has strongly advocated the implementation of an electronic health record (EHR), to ensure delivery of more cost-effective, efficient and productive healthcare. As enumerated by Steward [15], EHR will facilitate communications amongst departments in the hospital, reduce errors, give complete and an accurate overview of patients record; a crucial component in the treatment of patients. It will further allow for storage of digital images not possible with paper based records and create an overall efficiency in the running of the health care systems.

\section{Measures for Reducing Wait Time}

Measures for reducing wait times in ERs will benefit both patient and staff as well as the hospital managers and government, because patients' confidence in ERs' services will not dwindle, thus reducing morbidity and mortality-resulting in the achievement of government's intention of providing quality health care and wellness for its citizens. As evidenced by research the use of EHRs saves documentation time for nurses and since one of the procedures in ERs is for patients to see a nurse, at least a measure of time will be saved. Other methods for wait time reduction as reported in literature ranged from reviewing and modifying of ERs processes, to increasing staff, to streaming of patients according to the gravity of their illnesses, to creating centers that are similar to ERs (urgent care centers), and to using telemedicine, another branch of medical informatics. Nagurney [6] proposed that if patients bring to the ERs a list of their current medications, supplements they are taking, names and contact numbers of their doctors, this will assist physicians to make faster decisions on them, thereby reducing wait time. This practice is similar to patients coming along to ERs with a personal health record (PHR) i.e., portable digitized health information of a patient which can be worn by an unconscious patient or one too ill to provide meaningful information. However, the stumbling blocks that have been identified to the success of the various methods have been:

1. Cost effectiveness with the solution of increase of staff

2. Patients accessed as low acuity are hastily dispatched under the streaming method, while there is, conflict between what health informatics designer perceived as best solution and what users' expectations are. 


\section{The Implication for Medical Practice and Medical Informatics}

As enumerated by Shortliffe \& Blois [16], computer based medical records are a set of processes put together by people and not one solution picked off the shelf. The implication for medical practice and medical informatics practitioners is that they must collaborate and standardize:

- ERs processes,

- Acceptable wait times.

- What information patients require in ERs in order to have the right attitude towards wait times

- Jointly commission a digital solution which is integrated and interoperable and can be used by any ER.

- Doctors have to be well informed, to hasten their decision making which will reduce time spent on a patient'

\section{RESEARCH FINDINGS}

The summary of the research findings was tabulated and presented as follows:

Table-1: Summary of Research Findings

\begin{tabular}{|c|c|c|c|c|}
\hline Author(s) & The Research Focus & $\begin{array}{l}\text { Design } \\
\text { Methodology(ies) }\end{array}$ & Findings & Gaps Identified \\
\hline $\begin{array}{l}\text { Chan, Arendts, \& Wong } \\
\text { [8]. }\end{array}$ & $\begin{array}{l}\text { Staff perception of } \\
\text { causes of delay }\end{array}$ & $\begin{array}{l}\text { Quantitative longitudinal } \\
\text { study }\end{array}$ & $\begin{array}{l}\text { Staff perceptions } \\
\text { regarding delay do not } \\
\text { correlate well with real- } \\
\text { time analysis result. }\end{array}$ & $\begin{array}{l}\text { Consistency of data collected } \\
\text { by software depended on } \\
\text { timely and accurate input of } \\
\text { data. }\end{array}$ \\
\hline Lyneham, [17]. & Violence on staff in ERs & $\begin{array}{l}\text { Mixed method study } \\
\text { (semi-structure interview } \\
\text { followed by } \\
\text { questionnaire). }\end{array}$ & $\begin{array}{l}\text { The public lacked } \\
\text { understanding } \\
\text { of the triage categories } \\
\text { and clients did not } \\
\text { accept that others } \\
\text { required more } \\
\text { immediate attention. }\end{array}$ & $\begin{array}{l}\text { Solutions proffered were } \\
\text { mostly paper based reports } \\
\text { and were targeted at policy } \\
\text { and staff attitude. The ER } \\
\text { process was not addressed. }\end{array}$ \\
\hline $\begin{array}{l}\text { Estey, Ness, Saunders, } \\
\text { Alibhai, \& Bear, [18] }\end{array}$ & Overcrowding in ERs & Interview of focus group & $\begin{array}{l}\text { Inefficient access to ER } \\
\text { beds (stretchers) }\end{array}$ & $\begin{array}{l}\text { Solution can be found if } \\
\text { causes of overcrowding are } \\
\text { treated as interrelated. }\end{array}$ \\
\hline $\begin{array}{l}\text { Monzon, Friedman, } \\
\text { Clarke and Arenovich, } \\
{[19]}\end{array}$ & $\begin{array}{l}\text { Left without being seeing } \\
\text { by a doctor(LWBS) }\end{array}$ & Case control study & $\begin{array}{l}\text { Excessive wait time was } \\
\text { the most common } \\
\text { reason for leaving. }\end{array}$ & $\begin{array}{l}\text { The LWBS were low socio } \\
\text { economic wise and many did } \\
\text { not leave telephone contact } \\
\text { limiting the number } \\
\text { interviewed }\end{array}$ \\
\hline $\begin{array}{l}\text { Howell, Bessman and } \\
\text { Rubin, [20] }\end{array}$ & $\begin{array}{l}\text { Implementation of an } \\
\text { admission system using } \\
\text { telephone consultation } \\
\text { between ED physicians } \\
\text { and in-house hospitalists }\end{array}$ & Longitudinal qualitative & $\begin{array}{l}\text { Post-intervention, } \\
\text { admission time reduced } \\
\text { when beds are available } \\
\text { compared to pre- } \\
\text { intervention. }\end{array}$ & $\begin{array}{l}\text { Throughput of patients not } \\
\text { admitted was not examined. } \\
\text { Only when that is done can } \\
\text { the intervention be said to be } \\
\text { more efficient. }\end{array}$ \\
\hline Groth \& Gilliland, [9] & $\begin{array}{l}\text { Effect of providing wait } \\
\text { information on customer } \\
\text { reactions }\end{array}$ & $\begin{array}{l}\text { Quantitative } \\
\text { study(Experimental and } \\
\text { Control group) }\end{array}$ & $\begin{array}{l}\text { Providing information } \\
\text { had limited impact on } \\
\text { customers. }\end{array}$ & $\begin{array}{l}\text { The result was inconsistent, } \\
\text { as with earlier studies. }\end{array}$ \\
\hline $\begin{array}{l}\text { Poissant, } \quad \text { Pereira, } \\
\text { Tamblyn, Kawasumi, } \\
\text { [21] }\end{array}$ & $\begin{array}{l}\text { Impact of EHRs on } \\
\text { documentation time of } \\
\text { physicians and nurses }\end{array}$ & $\begin{array}{l}\text { Most studies reviewed } \\
\text { used time and motion } \\
\text { methodology }\end{array}$ & $\begin{array}{l}\text { The use of EHR reduced } \\
\text { time spent in } \\
\text { documentation for } \\
\text { nurses but increased } \\
\text { time for physicians }\end{array}$ & $\begin{array}{l}\text { Inconsistent between studies } \\
\text { that evaluated the efficiency } \\
\text { immediately after } \\
\text { implementation of the EHR } \\
\text { and those that had a longer } \\
\text { time lag }\end{array}$ \\
\hline $\begin{array}{l}\text { King, Ben-Tovim, \& } \\
\text { Bassham, [13] Ng, Vail, } \\
\text { Thomas, \& Schmidt, } \\
\text { [22] }\end{array}$ & $\begin{array}{l}\text { Streaming of patients } \\
\text { into groups in ERs using } \\
\text { the Lean Thinking ( a } \\
\text { mathematical model) }\end{array}$ & $\begin{array}{l}\text { Longitudinal descriptive } \\
\text { study }\end{array}$ & $\begin{array}{l}\text { Patients' flow improved, } \\
\text { wait time was reduced, } \\
\text { and aggression rate fell. } \\
\text { Patients were happy to } \\
\text { wait if they knew their } \\
\text { position in the queue }\end{array}$ & $\begin{array}{l}\text { Patients with seemly low } \\
\text { acuity were not attended to. }\end{array}$ \\
\hline $\begin{array}{l}\text { Steiner, Nichols, Blitz, } \\
\text { Tapper,Stagg, } \\
\text { Sharma,\& Policicchio, } \\
{[24],[23]}\end{array}$ & $\begin{array}{l}\text { Integration of other staff } \\
\text { e.g., nurse practitioners } \\
\text { (NPs), and physician } \\
\text { assistants (PAs). }\end{array}$ & $\begin{array}{l}\text { Observational study; } \\
\text { mixed methodology }\end{array}$ & $\begin{array}{l}\text { Reduction in wait time } \\
\text { for low acuity patient. }\end{array}$ & $\begin{array}{l}\text { Cost effectiveness not } \\
\text { considered }\end{array}$ \\
\hline Welch, \& Savitz, [25] & $\begin{array}{l}\text { Review of innovations } \\
\text { involving the } \\
\text { improvements in ER wait } \\
\text { time. }\end{array}$ & $\begin{array}{l}\text { Comparison } \\
\text { innovations }\end{array}$ & $\begin{array}{l}\text { Innovation in three } \\
\text { areas- physical plant } \\
\text { changes, technological } \\
\text { innovations, r and } \\
\text { process/flow changes, }\end{array}$ & $\begin{array}{l}\text { The results were not } \\
\text { statistically tested, therefore it } \\
\text { cannot be generalized. }\end{array}$ \\
\hline
\end{tabular}




\begin{tabular}{|c|c|c|c|c|}
\hline & & & $\begin{array}{l}\text { are needed in patients' } \\
\text { intake and front end } \\
\text { process to reduce wait } \\
\text { times. }\end{array}$ & \\
\hline $\begin{array}{l}\text { Ackerman, Tebb, Stein, } \\
\text { Frazee, } \\
\text { Schmidt, \& Gondey, } \\
\text { [22] }\end{array}$ & $\begin{array}{l}\text { A computer kiosk } \\
\text { designed to diagnose } \\
\text { and treat diseases } \\
\text { considered as not } \\
\text { emergent, thus reducing } \\
\text { wait time at ERs }\end{array}$ & $\begin{array}{l}\text { Longitudinal qualitative } \\
\text { study }\end{array}$ & $\begin{array}{l}\text { The pilot was found to } \\
\text { reduce wait time, but at } \\
\text { implementation it was } \\
\text { rejected by staff and } \\
\text { many patients were not } \\
\text { eligible for its use }\end{array}$ & $\begin{array}{l}\text { The challenges of technology } \\
\text { implementation when users } \\
\text { and designers differ in their } \\
\text { understanding of what } \\
\text { constitutes a workable } \\
\text { system. }\end{array}$ \\
\hline
\end{tabular}

\section{CONCLUSION}

There were limited studies on the causes of prolonged wait time. Research on impact of providing information to patients is still inconsistent. Further studies are needed in these areas to ensure better solutions for prolonged wait times. Most studies reviewed used single methodology, either quantitative or qualitative, but given the nature of prolonged wait time which has consequences on patients' behavior and staff perception, it is recommended that a mixed methodology approach be used to conduct future studies. This will ensure certain results in one analysis are looked at in more details through the other analysis. A system that can predict the causes of prolonged wait time with precision and further proffer solutions is an area health informatics designer can look into. In order to provide a cost effective solution, the hardware manufacturers also should be included in such studies.

\section{REFERENCES}

1. John A. Buzacott, Queueing Theory and Its Applications: York University Toronto, Canada

2. Okoli, C., \& Schabram, K. (2010). A Guide to Conducting a Systematic Literature Review of Information Systems Research. Sprouts: Working Papers on Information Systems, 10(26).

3. Hoot, N., \& Aronsky, D. (2008). Systematic Review of Emergency Department Crowding: Causes, Effects, and Solutions. Annals of Emergency Medicine, 52(2), 126-136.

4. Wilper, A. P., Woolhandler, S., Lasser, K. E., McCormick, D., Cutrona, S. L., Bor, D. H., \& Himmelstein, D. U. (2008). Waits To See An Emergency Department Physician: US Trends And Predictors, 1997-2004: Overcrowding by patients unable to obtain nonurgent care elsewhere might be worsening care for those with truly urgent conditions. Health Affairs, 27(Suppl1), w84-w95.

5. Soremekun, O. A., Takayesu, J. K., \& Bohan, S. J. (2011). Framework for analyzing wait times and other factors that impact patient satisfaction in the emergency department. The Journal of emergency medicine, 41(6), 686-692.

6. Nagurney, J. (2011). Why Are Waits In The Emergency Department So Long? Harvard Health Letter, $37(2), 5$.

7. Snyder, L. (2012). American College of Physicians ethics manual. Annals of Internal Medicine, 156(1_Part_2), 73-104.

8. Chan, A., Arendts, G., \& Wong, S. (2008). Causes of constraints to patient flow in emergency departments: A comparison between staff perceptions and findings from the Patient Flow Study. Emergency Medicine Australasia, 20(3), 234-240.

9. Smith, T. M., Cong, Z., Gilliland, K. L., Clawson, G. A., \& Thiboutot, D. M. (2006). Insulin-like growth factor-1 induces lipid production in human SEB-1 sebocytes via sterol response element-binding protein-1. Journal of investigative dermatology, 126(6), 1226-1232.

10. Blake, J. T., \& Carter, M. W. (1996). An Analysis Of Emergency Room Wait Time Issues Via Computer Simulation. Infor, 34(4), 263-273

11. Hoskins, E., Sayger, S. \& Westman J. (2002). Quality Improvement in Patient Distribution at a Major University Student Health Center. Journal Of American College Health [serial online], 50 (6),303.

12. Eilers, G. M. (2004). Improving Patient Satisfaction With Waiting Time. Journal Of American College Health, 53(1), 41-45.

13. King, D. L., Ben-Tovim, D. I., \& Bassham, J. (2006). Redesigning emergency department patient flows: Application of Lean Thinking to health care. Emergency Medicine Australasia, 18(4), 391-397.

14. Feau, S., Facchinetti, V., Granucci, F., Citterio, S., Jarrossay, D., Seresini, S., ... \& Ricciardi-Castagnoli, P. (2005). Dendritic cellderived IL-2 production is regulated by IL-15 in humans and in mice. Blood, 105(2), 697-702.

15. Steward, M. (2005). Electronic Medical Records. Journal Of Legal Medicine, 26(4), 491-506.

16. Shortliffe, E. M. \& Blois, M. S. (2006). The Computer Meets Medicine and Biology: Emergence of a Discipline in Biomedical Informatics pp. 3-45.

17. Lyneham, J. (2000). Violence In New South Wales Emergency Departments. Australian Journal of Advanced Nursing , 18(2), 817.

18. Estey, A., Ness, K., Saunders, D., Alibhai, A., \& Bear, R. (2003). Understanding the causes of overcrowding in emergency departments in the Capital Health Region in Alberta: a focus group study. CJEM , 5(2), 87-94.

19. Monzon, J., Friedman, S., Clarke, C., \& Arenovich, T. (2005). Patients who leave the emergency department without being seen by a physician: a control-matched study. CJEM: Canadian Journal Of Emergency Medicine, 7(2), 107-113.

20. Howell E, Bessman E, Rubin H. (2004). Innovations In Education And Clinical Practice Hospitalists and an Innovative Emergency Department Admission Process. JGIM: Journal Of General Internal Medicine [serial online]. March 2004;19(3):266-268. 
21. Poissant, L., Pereira, J., Tamblyn, R., \& Kawasumi, Y. (2005). The Impact of Electronic Health Records on Time Efficiency of Physicians and Nurses: A Systematic Review. Journal of the American Medical Informatics Association, 12(5), 505-516

22. Ackerman, S. L., Tebb, K., Stein, J. C., Frazee, B. W., Hendey, G. W., Schmidt, L. A., \& Gonzales, R. (2012). Benefit or burden? A sociotechnical analysis of diagnostic computer kiosks in four California hospital emergency departments. Social Science \& Medicine, 75(12), 2378-2385.

23. Ducharme, J., Alder, R. J., Pelletier, C., Murray, D., \& Tepper, J. (2009). The impact on patient flow after the integration of nurse practitioners and physician assistants in 6 Ontario emergency departments. CJEM: Canadian Journal Of Emergency Medicine, 11(5), 455-461

24. Steiner, I. P., Nichols, D. N., Blitz, S., Tapper, L., Stagg, A. P., Sharma, L., \& Policicchio, C. (2009). Impact of a nurse practitioner on patient care in a Canadian emergency department. CJEM: Canadian Journal of Emergency Medicine, 11(3), 207-214.

25. Welch, S., \& Savitz, L. (2012). Exploring Strategies to Improve Emergency Department Intake. Journal Of Emergency Medicine, 43(1), 149-158.

\section{About the authors:}
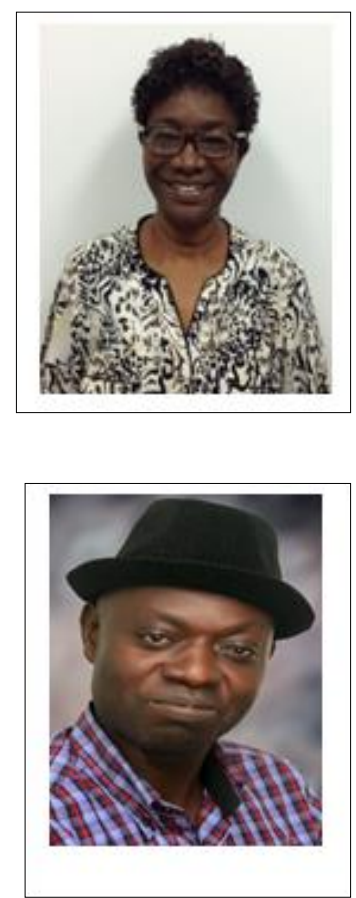

Ajibike. O. Itegboje Ph.D. Chief Lecturer, Department of Computer Technology, Yaba College of Technology, Lagos-Nigeria +234-8182338513

Ajibike Itegboje is a doctoral graduate of the department of Math and Science Education at Southern University A \& M, College, Baton Rouge. She holds the B.Sc. Math/Educ., M.Sc. Computer Science, M.Ed. (Math) of the University of Lagos, Nigeria and a post graduate diploma (PGD) in Computer Science of the University of Benin, Nigeria. Ajibike has published some papers in journals, conference proceedings, and two book chapters. She has also edited two conference proceedings. Her research interest is in the area of electronic learning; currently she is working on her $\mathrm{PhD}$. dissertation on "Mobile Adoption for Teaching and Learning Activities". She hopes to complete the program in May, 2014. Ajibike has over 30years of post- secondary school teaching experience and was the lead ACT coach for students of White Castle High School, Iberville Parish in 2013.

Yekini. N. Asafe is currently a researcher and Lecturer at Yaba College of Technology, Lagos-Nigeria. He was with Computer sciences department for a decade, before he was redeployed to computer engineering in the year 2015. He obtained his academic qualification as follows: M.Sc. in Computer Science, University of Lagos Nigeria (UNILAG); B.Sc. in Electronic and Computer Engineering, Lagos State University (LASU), and NCE (National Certificate in Education) in Physics Lagos State College of Education ljanikin (LACOED). He is a Member Nigeria Computer Society (NCS), International Association of Engineers (IAENG), International Association of Computer Science and Information Technology (IACSIT), and Member Institute of Electrical Electronic (MIEEE). He is a singular author, and co-author, of several academic/research publications that has features in some revered international journals and conference proceedings both in Nigeria and in abroad. He has writ-ten about seventeen textbooks in computer science and engineering. 